Transactions of the American Fisheries Society, Vol. 125, No. 2, 1996, pp. 187-195.

(C) American Fisheries Society. All rights reserved.

http://afs.allenpress.com/archive/1548-8659/125/2/pdf/i1548-8659-125-2-187.pdf

http://afs.allenpress.com/perlserv/?request $=$ get-archive\&ct $=1$

DOI: 10.1577/1548-8659(1996)125<0187:COMSIU>2.3.CO;2

ISSN: 0002-8487

\title{
Characteristics of Muskellunge Spermatozoa I: Ultrastructure of Spermatozoa and Biochemical Composition of Semen
}

\author{
FENG Lin, Li LIU, AND KONRAD DABROWSKI
}

School of Natural Resources. The Ohio State University.

Abstract. - We investigated the ultrastructure of spermatozoa and some physiological and biochemical parameters of semen in muskellunge Esox musquinongy. Ultrastructure of spermatozoa analyzed with scanning and transmission electron microscopes revealed a spherical head, $1.5 \mu \mathrm{m}$ in diameter. Unlike the spermatozoa of other teleost fishes, an elongated midpiece with abundant mitochondria was found to be characteristic for muskellunge spermatozoa. Three techniques for measuring sperm concentration, counting with a hemacytometer, spermatocrit, and spectropho-tometric methods, provided similar results $\left(19.7 \pm 6.1 \times 10^{9} \mathrm{sperm} / \mathrm{mL}\right)$. The spectrophotometry method is recommended because it is rapid and requires only small amounts of semen. Ionic concentrations and osmolality (289 \pm 16.8 milliosmols $/ \mathrm{kg})$ of seminal plasma were reported. Sodium $(129 \pm 6.7 \mathrm{mM})$ and potassium $(27.88 \pm 3.27 \mathrm{mM})$ concentrations were closer to levels found in the seminal plasma of salmonids than cyprinids. Aspartate aminotransferase (AspAT) activity was measured with and without supplement of pyridoxal phosphate (PLP) from sperm extracts. A 96\% increase of AspAT was found when PLP was included in the assay. We confirmed the presence of antiprotcinasc activity (against cod trypsin) in seminal plasma of muskellunge. Using the flow cytometry method, we estimated that the DNA stainability of muskellunge spermatozoa was $0.188 \pm 0.008$ limes that of red blood cells (TRBC) from diploid rainbow trout Oncorhynchus mykiss. The DNA stainability of muskellunge spermatozoa was significantly lower than that of muskellunge embryonic cells, which was 0.474 times that of the TRBC (2.21 pg DNA/ cell, based on the internal standard of TRBC of $4.66 \mathrm{pg}$ DNA/cell).

Muskellunge Esox masquinongy is one of the most popular sport fishes in the northcentral United States. Because of the failure of natural reproduction. annual stocking of this species is frequently required to maintain the population. In recent years, artificial manipulation of muskellunge gametogenesis has received increasing attention. However, only fragmentary information on physiology and biochemistry of spermatozoa (hereinafter, sperm) is available foresocids (Billard 1978; Duplinsky 1982; Koldras and Moczarski 1983). More baseline data are needed to establish sperm quality criteria and for studies of sex manipulation and sperm storage in this species.

Ultrastructure of sperm has been studied in 280 fish species from more than 100 families (Mattei 1991). However, only a brief description of sperm ultrastructure has been made for northern pike Esoxlucius (Billard 1970). Gwo and Arnold (1992) described the morphological changes of sperm after cryopreservation in Atlantic croaker Micropogonias undulatus. Further information on ultra-structure is needed for understanding sperm biology in esocids, which may be invaluable in developing sperm cryopreservation methods.

A quick and accurate assessment of sperm concentration is required for fertilization experiments and sperm cryopreservation. Sperm concentration assessed with a hemacytometer is widely used to measure sperm quality in fish. Spermatocrit (Bouck and Jacobson 1976) and spectrophotometric methods (Billard et al. 1971; Suquet et al. 1992; Ciereszko and Dabrowski 
1993) have been used as alternative methods to estimate sperm density.

Sperm of most teleost fish are quiescent in seminal plasma and are activated after being released into water. Potassium concentration and osmolality have been demonstrated to be the major factors that control the motility of salmonid and cyprinid sperm, respectively (Morisawaet al. 1983a, 1983b). We demonstrated that sperm motility in muskellunge was mainly regulated by osmolality and that calcium had an inhibitory effect (Lin and Dabrowski 1996). Thus, a determination of both the ionic concentration and osmolality of seminal plasma is important in this species. Cruea (1969) found that chloride concentration was much lower $(91.3 \mathrm{mM})$ in seminal plasma of northern pike Esox hicius than in salmonids (156-172.6 mM).

Activity of aspartate aminotransferase (AspAT, enzyme number 2.6.1.1) is a reliable biochemical indicator for mammalian and fish sperm quality (Brown et al. 1971; Ciereszko et al. 1990; Ciereszko and Dabrowski 1994). A significant correlation has been demonstrated between AspAT activity and sperm motility and fertilization rate in rainbow trout (Ciereszko and Dabrowski 1994). Changes in AspAT activity were observed in each step of sperm cryopreservation, and the activity has been used as an index of cryogenic damage in sperm and of their fertilizing ability in bovines (Pace and Graham 1970). The extent of disruption of sperm cells or changes in the membrane permeability due to storage or overmaturation could be monitored by the leakage of AspAT into plasma enzymes (Ciereszko and Dabrowski 1994). Proteinase inhibitor(s) found in the seminal plasma of several teleost species raise the question of the regulatory function of this protein in fish taxa that have anacrosomal sperm (Dabrowski and Ciereszko 1994).

In this study, we investigated the ultrastructure of sperm and evaluated three methods of estimating sperm concentration. We analyzed protein and ionic concentrations and osmolality of seminal plasma, AspAT activity of sperm extracts, and antiproteinase activity of seminal plasma. We also estimated the DNA content of muskellunge sperm by the flow cytometry method.

\section{Methods}

Collection of samples. - Muskellunge males, 3-5 years of age (703-991 mm total length), were captured by trap nets from the Clear Fork Reservoir, Ohio, during the spawning seasons (April-May) of 1993 and 1994. Semen was stripped from un-anesthetized fish by abdominal pressure and collected into a vial. Care was taken to avoid contamination of the semen sample with blood and urine. Semen was stored on ice for up to $6 \mathrm{~h}$ before being analyzed. Semen was also collected from fish maintained in ponds at the Minor E. Clark Fish Hatchery, Kentucky. Four of those semen samples were used for flow cytometry measurement of DNA content.

Ultrastructure of sperm. - Fresh semen was fixed with a paraformaldehydeglutaraldehydeosmium tetroxide mixture, following the method of Lahnsteiner and Patzner (1991). The specimens were dehydrated in a graded ethanol series and embedded in EPON 812. Thin sections were stained with uranyl acetate and lead citrate for transmission electron microscopy (TEM). For scanning electron microscopy (SEM), specimens were dehydrated, subjected to critical point drying, and then coated with a film of evaporated gold-platinum. Samples were observed and photographed with a Philips CM 12 electron microscope.

Estimation of sperm concentration. - Sperm density in 19 males was evaluated by procedures described by Ciereszko and Dabrowski (1993). Briefly, sperm counting was done with a Neubauer counting chamber after $1,000 \times$ dilution with $0.75 \% \mathrm{NaCl}$ plus $0.6 \% \mathrm{KCl}$. Spermatocrit was determined after centrifugation at 12,500 revolutions per minute (rpm) for 10 
min in 75-mm capillary tubes in a Beckman Microfuge 12, equipped with a capillary tube rotor. Optical density of diluted semen $(1,000 \times)$ was estimated with a Beckman DU-70 spectrophotometer with a wavelength of $610 \mathrm{~nm}$. Also, the effect of wavelengths on the optical density was estimated by scanning through the visible light range. The correlation among optical density at wavelengths of 400, 500, 700, and $800 \mathrm{~nm}$ was analyzed by using semen from 11 males.

Determination of protein and ionic concentrations and osmolality of seminal plasma. - Seminal plasma from four individual males was used to estimate ionic concentrations (April 1994). Seminal plasma was collected after centrifugation at $12,500 \mathrm{rpm}$ for $10 \mathrm{~min}$ at $4^{\circ} \mathrm{C}$ and stored at $-80^{\circ} \mathrm{C}$ before analysis. Concentrations of potassium, sodium, calcium, magnesium, phosphate, chloride, and other ions were analyzed by an inductively coupled plasma emission spectrometer (ICP, model ARL-3560, Applied Research Laboratory, Valencia, California). Osmolality of seminal plasma from 10 individual males was measured with a freezing point micro osmometer ( $\mu$ OSMETTE, Precision Systems, Inc., Natick, Massachusetts). The instrument was calibrated with 100 and 500 milliosmols (mosmol)/kg osmometry standards (Precision Systems, Inc.) before each measurement. Protein concentration was measured according to the Bradford (1975) method with the Coomassie protein assay (Pierce, Illinois) with bovine serum albumin as a standard.

Aspartate aminotransferase activity. - Aspartate aminotransferase activity was measured with a reduced nicotinamide adenine dinucleotide (NADH) method (340 nm), according to Bergmayer et al. (1986). Sperm pellets were stored at $-80^{\circ} \mathrm{C}$ before being analyzed. A subsample of sperm pellets was dissolved in $0.1 \%$ triton in $0.1 \mathrm{M}$ tris buffer at $\mathrm{pH} 8.2$ and stored in a refrigerator $\left(4^{\circ} \mathrm{C}\right)$ for $1 \mathrm{~h}$. Supernatant was separated through centrifugation at 12,000 $\mathrm{rpm}$ for $10 \mathrm{~min}$ at $4^{\circ} \mathrm{C}$. The sperm extract was incubated at $30^{\circ} \mathrm{C}$ for $10 \mathrm{~min}$ with a reaction mixture, with or without pyridoxal phosphate (PLP), that also contained L-aspartate, NADH, malate dehydrogenase, lactate dehydrogenase (Ciereszko and Dabrowski 1995). Aspartate aminotransferase activity was determined with a spectrophotometer (DU 620, Beckman). Protein concentration of sperm extracts was measured as described above.

Antiproteinase activity of seminal plasma. - Antiproteinase activity of seminal plasma was assayed following the method described by Bergmayer (1983) and Dabrowski and Ciereszko (1994). Inhibition of amidase activity of cod trypsin (Sigma, St. Louis, Missouri) was determined spectrophotometrically with $N$-benzoyl-DL-arginine- $p$-nitroanilide (BAPNA) as a substrate. The trypsin assay mixture contained $0.25 \mathrm{mM}$ BAPNA, 32-units (U) cod trypsin/L, and $20 \mathrm{mM}$ $\mathrm{CaCl}_{2}$ in $0.1 \mathrm{M}$ tris buffer ( $\mathrm{pH} \mathrm{8.2)}$, and activity was measured at $25^{\circ} \mathrm{C}$.

Measurement of DNA content by flow cytometry method. - Semen of 9 males (4 from the Minor E. Clark Fish Hatchery and 5 from Clear Fork Reservoir) was used in this experiment. Sperm was cryopreserved with an extender containing $0.6 \mathrm{M}$ sucrose and $10 \%$ dimethyl sulfoxide (Holtz 1993). Sperm pellets were thawed at room temperature. Sperm suspension $\left(10^{7}\right.$ sperm cells) was added to $1 \mathrm{~mL}$ staining solution, containing $50 \mathrm{mg}$ propidium iodide, $10 \mathrm{mg}$ ribonuclease A in 1 L Hematall (Fisher Scientific, Pittsburgh, Pennsylvania). Red blood cells of rainbow trout Oncorhynchus mykiss were used as both an external and internal standard. Blood samples to serve as standards were collected from the same individual rainbow trout maintained in our laboratory. Samples were stained overnight and filtered through a $60-\mu m$ nylon filter, then measured with an Elite flow cytometer (Coulter, Inc., Hialeah, Florida). We measured fluorescence, forward scatter, and 90-degree scatter to determine DNA content and cell size with the standard Elite workstation software. Data were collected from at least 10,000 events (cells) 
per male and used for analysis.

Statistical analysis. - All parameters of sperm were expressed as arithmetical means and standard deviations. One-way analysis of variance (ANO-VA) and student $t$-tests were used in comparisons among groups. Regression among three criteria of sperm density was performed with the StatView 512+TM, version 1.2 statistical software program (Abacus Concepts, Inc., Berkeley, California).

\section{Results and Discussion \\ Ultrastructure of Muskellunge Sperm}

Muskellunge sperm consisted of three distinct parts: head, midpiece, and tail (Figure 1). The head was round with a diameter of about $1.5 \mu \mathrm{m}$. No acrosome structure was present. The chromatin consisted of many clumps of dense granules surrounded by a nuclear envelope bordering the cytoplasmic membrane (Figure 1). The proximal centriole was perpendicular to the distal centriole. Both centrioles were located within the nuclear fossa and had a conventional 9+0 microtubular triplet construction. The midpiece was an elongated sleeve and was completely separated from the flagellum by an invagination of the cell membrane. Relatively large amounts of mitochondria were scattered throughout the midpiece. The cytoplasmic canal was present. The flagellum had the classical 9+2 axoneme structure. A cytoplasmic expansion (fin) was present on only one side of the flagellum. Ultrastructure of muskellunge sperm was comparable to sperm of northern pike described by Billard (1970). The elongated midpiece and abundant mitochondria of muskellunge sperm requires emphasis. Further investigations are necessary to clarify the possible relation between abundant mitochondria and the long duration of sperm movement in muskellunge.

\section{Estimation of Sperm Concentration}

Sperm concentration was $19.7 \pm 6.1 \times 10^{9}$ sperm cells $/ \mathrm{mL}$ (range, 7.46-30.0). The spermatocrit was $35.7 \pm 10.6 \%$ (range, 15.9-54.2\%). There were linear relationships among the three parameters of sperm density, as shown in Figure 2. Thus, all three techniques provided similar measurements of sperm density. Spermatocrit could be applied to estimate sperm concentration in muskellunge as has been shown in rainbow trout, yellow perch, Perca flavescens and lake whitefish Coregonus clupeaformis (Ciereszko and Dabrowski, 1993). However, spermatocrit cannot be used to evaluate sperm concentration in salmonids (Bouck and Jacobson 1976), northern pike (De Montalembert et al. 1980), and turbot Scophthalmus maximus (Suquet et al., 1992) due to a lack of correlation. The problem associated with using spermatocrit in muskellunge is that testing required at least $0.2 \mathrm{~mL}$ semen, which is a relatively high volume for muskellunge. The normal volume of semen collected from the Clear Fork Reservoir population is about $0.5 \mathrm{~mL}$ from a 3-6-kg fish. Based on our results, the spectrophotometric method is recommended for measurement of sperm density in muskellunge. This method is rapid and requires only $10 \mu \mathrm{L}$ semen. Optical density of sperm suspension declined with increasing wavelength; absorbance was from 0.48 at $320 \mathrm{~nm}$ to 0.22 at $900 \mathrm{~nm}$ for representative samples. The optical density of seminal plasma was not detectable with the same dilution in muskellunge. The reason optical density declined in sperm suspension is still unknown. Our further examination of optical density at 400, 500, 610, 700, and $800 \mathrm{~nm}$ from 11 males showed strong correlations $(r=1)$ among these wavelengths. This result indicated that measurements can be done with any of these wavelengths. However. optical density of sperm suspension only slightly declined in rainbow trout (Ciereszko and Dabrowski 1993). Suquet et al. (1992) reported 
changes of optical density of sperm suspension over 320-700 nm and minimal interference of seminal fluid at $420 \mathrm{~nm}$ in turbot.

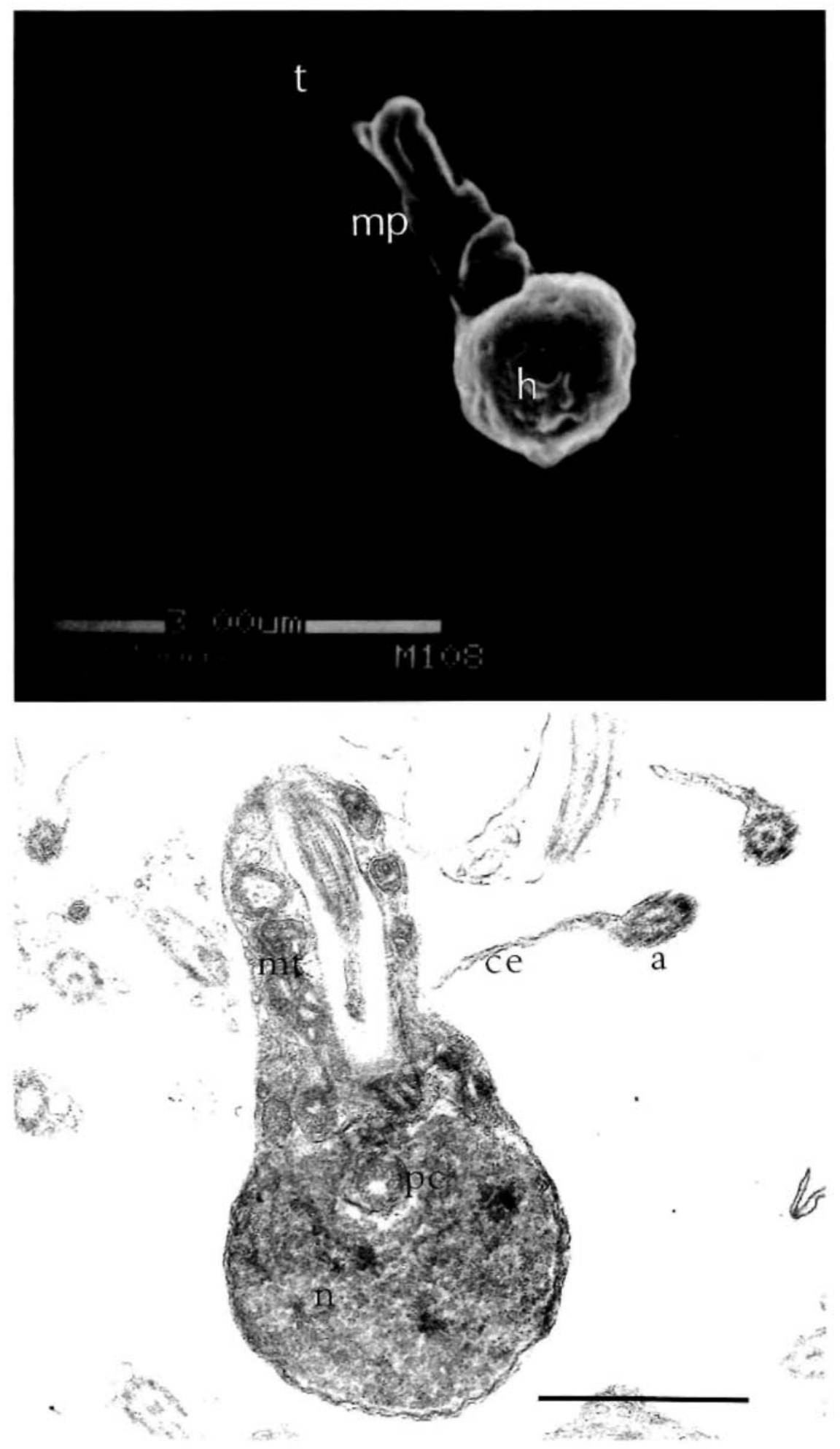


FIGURE 1. - Ultrastructure of muskellunge spermatozoa. The image at the top, generated by a scanning electron microscope shows the head (h). midpiece (mp), and tail (t). Bar $=3.0 \mu \mathrm{m}$. The image on the bottom, made by a transmission electron microscope, is of a longitudinal section of the spermatozoa and shows the compact nucleus (n); proximal centriole (pc); mitochondria (ml); theanoxeme (a), showing the usual $9+2$ pattern: and the cytoplasmic expansion (ce; fin). Bar $=1 \mu \mathrm{m}$.
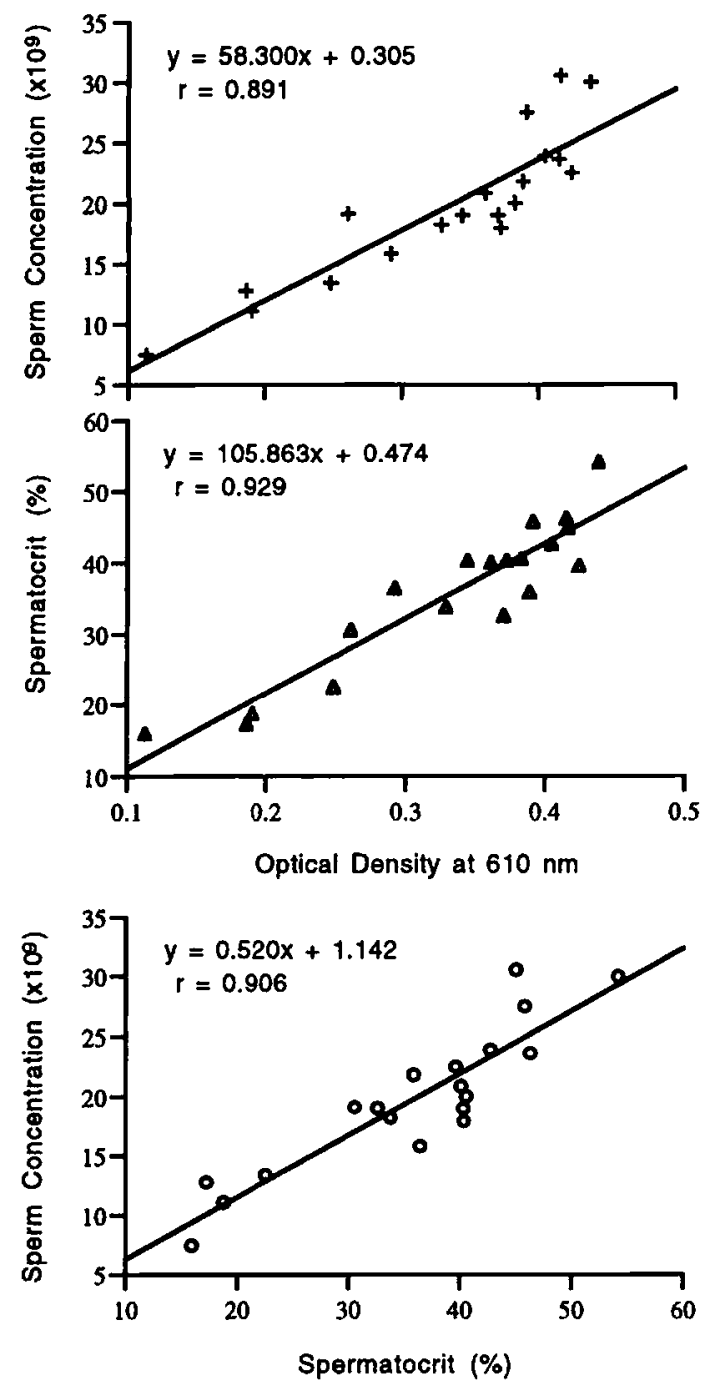

FIGURE 2. - Relationship of indirect measures (optical density and spermatocrit) to sperm density $(N=19)$. There were significant correlations among all three criteria of sperm density $(P=0.0001)$. 
TABLE 1 - Mean protein and ion concentrations and osmolality of muskellunge seminal plasma.

\begin{tabular}{lccc}
\hline Constiluent or variable & Mean & SD & $N$ \\
\hline Potussium (mM) & 27.88 & 3.27 & 4 \\
Sodium (mM) & 129.17 & 6.69 & 4 \\
Calcium (mM) & 1.72 & 0.26 & 4 \\
Magnesium (mM) & 1.05 & 0.11 & 4 \\
Phosphate $(\mathrm{mM})$ & 7.81 & 2.17 & 4 \\
Chloride $(\mathrm{mM})$ & 120.32 & 7.86 & 4 \\
Protein (mg/m) & 0.538 & 0.095 & 10 \\
Osmolatily (mosmol $/ \mathrm{kg})$ & 289.5 & 16.8 & 10 \\
\hline
\end{tabular}

\section{Ionic Concentration and Osmolality of Seminal Plasma}

Muskellunge seminal plasma showed a sodium concentration of $129.17 \mathrm{mM}$ (Table 1), which was similar to that of rainbow trout (127 mM: Morisawa et al. 1983b) and higher than that of common carp Cyphmts carpio (75 mM; Morisawa et al. 1983a). Potassium concentration (27.88 $\mathrm{mM})$ was lower than that of rainbow trout $(37.3 \mathrm{mM})$ and common carp $(70.2 \mathrm{mM})$. Sperm motility was regulated by a similar mechanism in both muskellunge and common carp. Further information is necessary to understand the relationship between ionic composition and regulation of sperm motility. Calcium, magnesium, and chloride concentrations were comparable to those of rainbow trout. Calcium concentration in common carp seminal plasma varied between 2.11-2.88 $\mathrm{mM}$ during the sperm production season (Kruger et al. 1984). Osmolality of muskellunge seminal plasma was slightly lower than that of rainbow trout (297 mos-mol $/ \mathrm{kg})$ and common carp (302 mosmol/kg). In common carp, Kruger et al. (1984) found seasonal variation in osmolality of seminal plasma. The differences in osmolality between seminal plasma of common carp and muskellunge were not evident at the time of spawning. Osmolality of muskellunge seminal plasma was measured with frozen samples because the osmometer was not available at the time of sample collection. In order to examine the effect of storage on osmolality, the osmolality of seminal plasma from 13 yellow perch was measured both before and after freezing. There was no significant difference in osmolality between fresh and frozen samples $(P$ $>0.05$, paired $t$-test, unpublished results). 


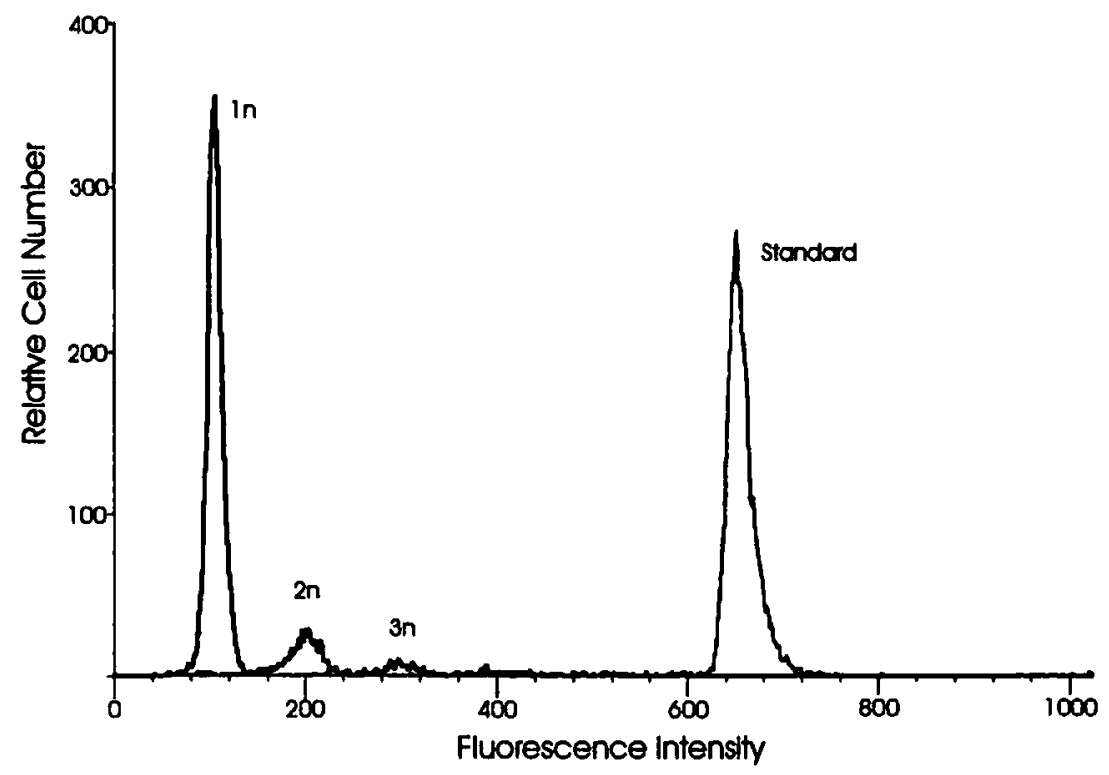

FIGURE 3. - Representative fluorescence distributions of muskellunge sperm and rainbow trout red blood cells. Samples were stained with propidium iodide. Haploid (1n) sperm accounted for $85.3 \%$ of the total cells and had a mean fluorescence intensity of 102.7; diploid (2n) sperm (7.9\% of the total) had a mean fluorescence intensity of 200.0; triploid (3n) sperm (1.9\%) and had a mean fluorescence intensity of 299.5. Rainbow trout red blood cells serving as a standard had a mean fluorescence intensity of 641.8.

\section{Aspartate aminotransferase and Antiproteinase Activity}

Aspartate aminotransferase activity of muskellunge sperm extracts was 1,192 \pm 196 $\mathrm{mU} / \mathrm{mg}$ protein without PLP and 2,344 $\pm 163 \mathrm{mU} / \mathrm{mg}$ protein with PLP $(N=10)$. Supplements of exogenous coenzyme in the preincubation mixture produced a significant $(P<0.001)$ increase in AspAT activity (96\%). This increase suggested that only partial enzyme activity was measured without PLP. Thus, measuring AspAT activity with PLP was recommended. The AspAT activity of muskellunge sperm extracts appeared to be higher than that of rainbow trout and lake whitefish (Ciereszko and Dabrowski 1994). However, different methods of sperm preparation for the estimation of AspAT activity limit the direct comparison.

Seminal plasma antiproteinase activity was $88.7 \pm 38.3 \mathrm{U} / \mathrm{L}$, which was considerably lower than that of rainbow trout $(396.0 \mathrm{U} / \mathrm{L})$ and yellow perch $(905.2 \mathrm{U} / \mathrm{L}$; Dabrowski and Ciereszko 1994). Dabrowski and Ciereszko (1994) recently demonstrated for the first time the existence of the proteinase inhibitor(s) in seminal plasma of rainbow trout, lake whitefish, and yellow perch. We confirmed the existence of an anti-cod trypsin activity in the seminal plasma of muskellunge. Further studies are required to determine the biological function of this protein.

\section{Sperm DNA Content}

Mean fluorescence of muskellunge sperm $(N=9)$ was $0.188 \pm 0.008$ times that of diploid rainbow trout red blood cells that were used as a standard (Figure 3). Assuming that the internal standard of rainbow trout red blood cells (TRBC) contained $4.66 \mathrm{pg}$ DNA/cell (Johnson et al. 1987; Lockwood and Derr 1992), haploid sperm cells of muskellunge contained $0.88 \pm 0.01 \mathrm{pg}$ DNA/cell. However, the DNA content of muskellunge sperm was significantly different $(P<$ 
0.0001) from half of the DNA content of diploid embryonic cells, which was 0.474 that of TRBC (2.21 pg DNA/cell, unpublished data). The underestimation of DNA content of sperm might be partially explained by the condensed structure of sperm chromatin. Evenson et al. (1986) demonstrated that the DNA stain-ability of spermatozoa was significantly lower than that of diploid cells in propidium iodide and seven other dyes in mouse. Variations of dye binding capacity in different cell populations could cause ambiguity in estimation of the correct DNA content of the species (Shankey 1993; Tiersch and Wachtel 1993). Thus, one should be cautious when choosing sperm as a standard for ploidy identification and estimation of haploid DNA content. We found that two smaller peaks corresponding to 2 and 3 times the haploid sperm occurred in the flow cytometric histograms. Software gating to exclude the sperm doublets did not eliminate these peaks. This suggests the possible existence of $2 n$ and $3 n$ sperm in muskellunge, which may be of great interest in ploidy manipulation of this species. Allen et al. (1986) also reported the existence of peaks (in decreasing abundance) at every ploidy level up to 6n from sperm samples of diploid grass carp Ctenopharyngodon idella. They attributed peaks at $3 n$ and up to cell aggregates. The $2 n$ and $3 n$ sperm, if viable, could be sorted and used to produce triploids and tetraploids without the need for chromosomal manipulation, such as heat shock or pressure treatments, that might cause damage to chromosomes and threaten the survival of embryos.

\section{Acknowledgments}

We thank John D. Harder of Department of Zoology and Jennifer Tomsen of the School of Natural Resources, The Ohio State University, for their critical reading of this manuscript. Thanks are due for Andrzej Ciereszko for his valuable discussions. We appreciate helpful cooperation in sampling gametes from Richard Day, Frank Kapler, and Bruce Bartens of the Ohio Department of Natural Resources. Joseph O. Trask, Jr., of the Comprehensive Cancer Center offered technical help in operating the flow cytometer. Jose Diaz of Department of Zoology, and Ann Osterfeld and Kathleen Wolken of the Campus Microscopy and Imaging Facility helped with electron microscopy preparation. This work was funded by the Federal Aid in Sport Fish Restoration Program (project F-69-P, Fish Management in Ohio) administered jointly by the United States Fish and Wildlife Service and the Ohio Division of Wildlife. Salaries were partly provided by the state and federal funds appropriated to the Ohio Agriculture Research and Development Center (OARDC). This is OARDC manuscript 47/95.

\section{References}

Allen, S. K.. Jr.. R. G. Thiery. and N. T. Hagstrom. 1986. Cytological evaluation of the likelihood that triploid grass will reproduce. Transactions of the American Fisheries Society 115:841-848.

Bergmayer, H. U. 1983. Methods of Enzymatic Analysis, 3rd edition, volume V. Verlag Chemie, Basel, Switzerland.

Bergmayer, H. U.. M. Horder. and R. Rej. 1986. Approved recommendation (1985) on IFCSS methods for the measurement of catalytic concentration of enzymes. Part. 2. IFCSS method for aspartate aminotransferase (L-aspartate: 2-oxoglutarate aminotransferase, EC 2.6.1.1). Journal of Clinical Chemistry and Clinical Biochemistry 24:497-510.

Billard, R. 1970. Ultrastructure comparee de spermalozoides de quelques poissons teleosteens. Pages 71-83 in B. Baccetti, editor. Comparative spermatology. Academic Press, New York.

Billard, R. 1978. Changes in structure and fertilizing ability of marine and freshwater fish spermatozoa diluted in media of various salinities. Aquaculture 14:187-198.

Billard. R., B. Breton, and B. Jalabert. 1971. La production spermatogenetique chez la truitc. Annales de Biologie Animale Biochimie Biophysique, 11: 90-212.

Bouck, G. R.. and J. Jacobson. 1976. Estimation of salmonid sperm concentration by microhematocrit technique. Transactions of the American Fisheries Society 105:534-535.

Bradford, M. M. 1975. A rapid and sensitive method for the quantitation of microgram quantities of protein utilizing the principle of protein-dye binding. Analytical Biochemistry 72:248-254.

Brown. K. I., B. G. Crabo. E. F Graham, and M. M. Pace. 1971. Some factors affecting loss of intracellular enzymes from spermatozoa. Cryobiology 8: 220-224. 
Ciereszko, A., and K. Dabrowski. 1993. Estimation of sperm concentration of rainbow trout, whitelish and yellow perch using a spectrophotometric technique. Aquaculture 109:367-373.

Ciereszko, A., and K. Dabrowski. 1994. Relationship between biochemical constituents of fish semen and fertility: the effect of short-term storage. Fish Physiology and Biochemistry 12:357-367.

Ciereszko, A., and K. Dabrowski. 1995. Spectrophotometric measurement of aspartate aminotransferase activity in mammalian and fish semen. Animal Reproduction Science 38:167-176.

Ciereszko, A., C. Jablonowska, and J. Strzezek. 1990. Aspartate aminotransferase activity in motile and immolile spermatozoa fractions of frozen-thawed boar semen obtained after filtration on columns filled with chitin. Animal Reproduction Science 23: 237-244.

Cruea, D. A. 1969. Some chemical and physical characteristics of fish sperm. Transactions of the American Fisheries Society 98:785-788.

Dabrowski, K., and A. Ciereszko. 1994. Proteinase inhibitor(s) in seminal plasma of teleost fish. Journal of Fish Biology 45:801-809.

De Montalembert, G., J. Marcel, and R. Billard. 1980. La spermiation chez le brochet. 1. Evolution de la quantite de sperme recolte au cours de la saison de reproduction. Bulletin Francais de Pisciculture 276: 90-103.

Duplinsky, P. D. 1982. Sperm motility of northern pike and chain pickerel at various $\mathrm{pH}$ values. Transactions of the American Fisheries Society 111:768-771.

Evenson, D, Z. Darzynkiewicz, L. Jost, E Janca, and B. Ballachey. 1986. Changes in accessibility of DNA to various fluorochromes during spermatogenesis. Cytometry 7:45-53.

Gwo, J.-C, and C. R. Arnold. 1992. Cryopreservation of Atlantic croaker spermatozoa: evaluation of morphological changes. Journal of Experimental Zoology 264:444-453.

Hollz, W. 1993. Cryopreservation of rainbow trout (Oncorhynchus mykiss) sperm: practical recommendations. Aquaculture 110:97-100.

Johnson, O. W., F. M. Utter, and P. S. Rabinivitch. 1987. Interspecies differences in salmonid cellular DNA identified by flow cytometry. Copcia 1987:1001-1009.

Koldras, M., and M. Moczarski. 1983. Properties of pike Esox lucius L. milt and its cryopreservation. Polskie Archiwum Hydrobiologii 30:69-78.

Kruger, J. C. De W., G. L. Smith, J. H. J. Van Vuren, and J. T. Ferreira. 1984. Some chemical and physical characteristics of the semen of Cyprinus carpio L. and Oreochromis mossamhicus (Peters). Journal of Fish Biology 24:263-272.

Lahnsteiner, F, and R. A. Patzner. 1991. A new method for electron-microscopical fixation of spermatozoa of freshwater teleosts. Aquaculture 97:301-304.

Lin, F, and K. Dabrowski. 1996. Characteristics of muskellunge spermatozoa II: effects of ions and osmolality on sperm motility. Transactions of the American Fisheries Society 125:195-202.

Lockwood, S. F, and J. N. Derr. 1992. Intra- and interspecific genome-size variation in the Salmonidae. Cytogenetics and Cell Genetics 59:303-306.

Mattei, X. 1991. Spermatozoon ultrastructure and its systematic implications in fishes. Canadian Journal of Zoology 69:3038-3055.

Morisawa, M., K. Suzuki, and S. Morisawa. 1983a. Effects of potassium and osmolality on spermatozoa motility of salmonid fishes. Journal of Experimental Biology 107:105-113.

Morisawa. M., K. Suzuki, H. Shimizu. S. Morisawa. and K. Yasuda. 1983b. Effect of osmolality and potassium on motility of spermatozoa from freshwater cyprinid fishes. Journal of Experimental Biology 107:95-103.

Pace, M. M., and E. F. Graham. 1970. The release of glutamicoxaloacetic transaminase from bovine spermatozoa as a test method of assessing semen quality and fertility. Biology of Reproduction 3: 140-146.

Shankey, T. V., and seven coauthors. 1993. Guidelines for implementation of clinical DNA cytometry. Cytometry $14: 472-477$.

Suquet. M.. H. M. Omnes, Y. Normant. and C. Fauvel. 1992. Assessment of sperm concentration and motility in turbot (Scophthalmus maximus). Aquaculture 101:177-185.

Tiersch, T. R., and S. S. Wachtel. 1993. Sources of error in screening by flow cytometry for the effects of environmental mutagens. Environmental Toxicology and Chemistry 12:37-42. 